\title{
Characterization and Potential of Acid Fermentative and Proteolytic Natural Microflora in Several Products of Traditional Dadih from Lembah Gumanti District West Sumatra, Indonesia
}

\author{
N. Nurmiati*, P. Periadnadi, F. Alamsyah and F. Sapalina \\ Department of Biology, Faculty of Mathematics and Natural Sciences, \\ University of Andalas, Indonesia \\ *Corresponding author
}

K e y w or d s
$\begin{aligned} & \text { Characterization, Dadih, } \\ & \text { LembahGumanti } \\ & \text { Regency, Natural } \\ & \text { microflora, Probiotics }\end{aligned}$
Article Info
Accepted:
26 February 2018
Available Online:
10 March 2018

A B S T R A C T

\section{Introduction}

Natural wealth and culture from Minangkabau are complemented by the delicacy of its unique food. Each region in West Sumatra has its own specific food. Dadih is a traditional product that is spontaneously fermented from water buffalo milk has long been widely known in West Sumatra with the variety of uses such as in traditional ceremonies, eaten together as dessert, as medicine and in certain areas served as traditional delivery food.
Dadih (or Dadiah in Minangkabau dialect) is an original and traditionally food from West Sumatra, fermented fromwater buffalo milk in a bamboo tube and covered with with banana leaves and/or plastic when marketed. Visually a good dadihis bluish white, has a compact and smooth texture, slightly sour and tasty (Nurmiati, 2006, Nurmiati and Periadnadi, 2010). The term of dadih generally means clot and in Indonesian General Dictionary means concentrated and thickened buffalo milk (Poerwadarminta, 1976). In foreign languages, 
dadih can be interpreted as Curd/Quark/Young cheese (moisture content 73-87\%), which means cheeses that pass through slightly ripening with a little sour taste (Tauefel et al., 1993). The nutrition in these product according to Donhauser (1997) every $100 \mathrm{~g}$ consists of $10.8 \mathrm{~g}$ protein, $4.4 \mathrm{~g}$ fat, $3.6 \mathrm{~g}$ carbohydrates, $120 \mathrm{mg}$ calcium, $50 \mu \mathrm{g}$ vitamin $\mathrm{A}, 290 \mu \mathrm{g}$ vitamin B2 and $1 \mu \mathrm{g}$ vitamin B12.

Dadih is a biotechnology product of dairy based that using microbes in its production processes such as yoghurt, sour milk, young cheese, cheese and butter. Minangkabau (West Sumatra) society also has traditional dairy fermented products, named as dadih. Dadih is well known in West Sumatra with can be eaten directly with rice as a dessert, with chips with the addition of palm sugar or honey, served in a traditional dinner, as a mixture of medicinal ingredients. However the community still do not understand the benefitsof this food, then dadih begins to disappear in the market and can only be found around the production areas. Because of the nutrition of dadih, dadih is also as supporting medium of healthy digestion because the presence of beneficial microbes (Lactic Acid Bacteria) (Nurmiati, 2010).

In a previous study of ten isolates, ten isolates of Lactic Acid Bacteriapotentially producer glutamic acidwere isolated from Dadih, which the highest production was $41.73 \mathrm{mg} / \mathrm{L}$ by isolate Lactobacillus sp. can be as precursor of $\gamma$-Amino Butyric Acid (GABA) induced heat stress in broiler (Marlida, Harnentisdan Nurmiati, 2016). In addition to being a healthy food, dadih is also used for alternative medicine ingredients because of the benefits of its natural probiotics. Although, Indonesia is not the main milk producer, but dadih is the only one of the fermented milk productin the category of Indonesian probiotic food. Dadih is also a functional food, according to Fueller (1989) a functional food means as a food containng life microbes that if it is consumed will have a therapeutic impact on the body by improving the balance of microfloras in the digestive tract.

As a functional food, milk fat turns into fatty acids that through emulsifying in the blood can lower blood serum cholesterol levels. While the milk protein as casein was often labeled for allergies, through fermentation will be degraded into amino acids that are easier absorbed by the body. There are many advantages of dadih rather than ingredients themselves because dadih is a natural food of unboiled milk. Scientifically, fermentation in dadih involves bacteria, most of the fresh milk natural probiotic bacteria (Nurmiati, 2006 and 2007). Basically, dadih can be interpreted as Curd/Quark/Young cheese and in there are amino acid and fatty acids, glycerol, minerals, vitamins (A, B2, B12, lecithin from their raw materials), enzymes and probiotics (Czermak 1993).

Basically, most probiotics in fermented milk or lactic acid fermentation products consist of groups of lactic acid bacteria. Lactic acid bacteria are a group of Gram-positive bacteria united by constellation of morphological, metabolic and physiological characteristics. The general description of the bacteria included in the group is Gram-positive, nonsporing, non-respiring cocci or rods, which produce lactic acid as the major end product during the fermentation of carbohydrates (Axelsson, 1993 inSalminen and Wright, 1993).

Solok regency, especially in Lembah Gumanti district is one of dadih suppliers in West Sumatera. According to BPS of Solok Regency (2014) this region is topographically varies between plains, valleys and hills, from 329 mto 1458 mabove the sea level, with an average of 14 rainy days/month. The average rainfall of LembahGumanti is 211, 25 
$\mathrm{mm} / \mathrm{month}$. Based on the climate and topography, the Lembah Gumanti is the main supplier region of dadih in West Sumatera. Dadih products in this area packed continually and marketed to the surrounding cities. This research was conducted on several traditional dadih products in Lembah Gumanti district, Solok regency. In general, research about dadih was done (Nurmiati, 2005, 2006, 2007; Nurmiati and Periadnadi, 2010) but the presence of natural microflora and potential bacteria for fermentation dadih as a fermentative bacteria dadih has not been studied.

\section{Materials and Methods}

\section{Dadih samples}

Dadih were obtained from three area in Lembah Gumanti, they are Cubadak, Aia Sunsang and AiaAbu area. The study was donein survey method and the data were analyzed descriptively. The sampling was done by purposive sampling for each dadih in LembahGumanti. Bamboo species used for dadih is bamboo gombong (Gigantochloa verticillata). Here is a picture of bamboo tube used for Dadih (Fig. 1).

\section{The existence of natural microflora in dadih}

The existence of natural microflora was observed by the counting the colony of the bacteria grew on the media Glucose Peptone Agar (GPA), GPA+CaCO3, and Skim Milk Agar (SMA) (Nurmiati, 2005). The GPA mediumwas used to determine the total presence of natural microflora, $\mathrm{GPA}+\mathrm{CaCO}_{3}$ medium was used to determine acid fermentative bacteria and SMA medium was used to determine the proteolytic bacteria (Periadnadi and Nurmiati, 2010). The existence of microflora signed with the formation of clear zone around the colony after 24 hours incubation. Ethanol + $\mathrm{CaCO} 3$ Agarmedium is a selective medium Ethanol medium is used to differentiate lactate or acetate groups. Only acetic bacteria can use alcohol as a source of Carbon in the media, which is characterized by the formation of clear zone around the colony becaused of acetic acidformed in the medium will dissolve the CaCO3 (Periadnadi and Nurmiati, 2010).

\section{Isolation of dadih fermenting microflora}

The largest colony from each different colony grew on the $\mathrm{GPA}+\mathrm{CaCO} 3$ medium were selected after 24 hours and re-isolated by streak plate using Nutrient Agar medium to obtain isolates from dadih. The isolates obtained were coded according to their origin region, dadih from Cubadak area with DCU code, dadih from AiaSunsang area with DAS code and dadih from AiaAbu area with DAA code.

\section{Characterization of potential isolates}

Characterization of potential bacterial cells include Gram Staining, Motility test inSemisolid Nutrient Agar medium, catalase test with 3\% Hydrogen Peroxide.

\section{Pathogenicity test}

Medium Blood Agar used to test the pathogenicity of isolates that have been obtained. The production of hemolysis is considered to be a positive result determined by the presence of a hemolysis zone formed by bacterial isolates (Osek, 2004).

\section{Results and Discussion}

The existence of natural microflora in Dadih

In several traditional dadih products of LembahGumanti district can be found a 
number of microflora on medium GPA and the bacteria are the dominant microflora group in dadih products. In $\mathrm{GPA}+\mathrm{CaCO}_{3}$ medium found acid fermentative bacteria and in SMA medium obtained proteolytic bacteria. The following table shows the presence of microflora in several dadih products in LembahGumanti.

Based on Table 1, it can be seen the presence of microflora in several dadih products from three producing areas in LembahGumanti. Total of microflora in dadih AiaSunsang is $185.10^{7} \mathrm{cfu} / \mathrm{g}$, followed by dadihCubadak $142.10^{7} \mathrm{cfu} / \mathrm{g}$ and dadihof AiaAbu $138.10^{7} \mathrm{cfu} / \mathrm{g}$. The highest microflora in dadih LembahGumanti district is dadihfrom AiaSunsang, while the lowest microflora in dadih LembahGumanti district is dadihfrom AiaAbu. The difference in amount microflora obtained from each dadih product caused duration dadih storage in the respective region of origin, resulting in total difference in the presence of bacteria from various natural dadih products. This is in accordance with Nurmiati (2007) which states that the number of bacterial colonies in dadih is different because of several factors, the basic ingredients of milk, namely the duration of dadihstorage in the market, topography and regional climate. The presence of natural microflora in dadih products can be known using GPA medium, here are the pictures of the existence of natural microflora in dadih product from Cubadak area, AiaSunsang and AiaAbu.

In figure 1 it can be seen that the presence of dadih natural microflora in GPA medium. The calculation of microflora has been done in $G P A$ medium after incubation for 48 hours at $37^{\circ} \mathrm{C}$. Nurmiati (2005) reported that GPA medium is a common medium used to see the presence of natural microflora. Basically, all bacteria like sugar and a little peptone for its growth. But other microbes can also grow on this medium such as yeast and mould. The type of mould that can grow in dairy products like Geotrichum candidum. This is supported by Etienne et al., (2008) stating that $G$. candidum is a widespread fungus. $G$. candidum can be found in dairy products such as cheese and yoghurt.

The bacterial growth medium may also affect the total presence of bacteria in dadih, which states that the presence of the number of bacteria in dadih among others influenced by the availability of substrates in the media for its growth. According to Buckle (1987), the main factors affecting the growth of microbes are nutrients, temperature, water and oxygen (especially for aerobic microbes).

Acid-Fermentative bacteria are known to exist using $\mathrm{GPA}-\mathrm{CaCO}_{3}$ medium. Based on Table 1 , the number of acid fermentative bacteria in dadih AiaSunsang is $70.10^{7} \mathrm{cfu} / \mathrm{g}$, followed by dadih from AiaAbu $60.10^{7} \mathrm{cfu} / \mathrm{g}$ and dadih from Cubadak $14.10^{7} \mathrm{cfu} / \mathrm{g}$. Dadih from AiaSunsang and AiaAbu areas has a higher total presence of acid fermentative bacteria than the total presence of proteolytic bacteria. This proves that in dadih of AiaSunsang and AiaAbu region is dominated by acid fermentative bacteria in the process of fermentation of dadih.

On below is a picture of the presence of the natural bacteria of fermentation of dadih from the three producers dadih in $\mathrm{GPA}-\mathrm{CaCO}_{3}$ medium.

Based on Figure 2 can be seen the existence of natural bacteria of fermented dadih in $\mathrm{GPACaCO}_{3}$ medium. This medium is a medium used to see acid fermentative bacteria that has the potential as a lactic acid bacteria. In $\mathrm{GPA}-\mathrm{CaCO}_{3}$ medium can be seen the ability of bacteria in producing acid by observing large diameter of halo area formed on medium $\mathrm{GPA}-\mathrm{CaCO}_{3}$. This is in 
accordance with the opinion according to Nurmiati (2007), that halo area that has a wider diameter describes the ability of bacteria in producing higher acid. According Nurmiati and Periadnadi (2010) acid fermentative bacteria evidenced by the formation of halo region as a result hydrolysis of bacteria to acid in medium $(G P A)$ added Calcium Carbonate (CaCO3). Function calcium carbonate to neutralize the acid produced by bacteria to form colonies around the bacterial colonies.

The halo zone formed around bacterial colonies shows that the bacteria produce acid. Bacteria grown in $\mathrm{GPACaCO} 3$ medium have the ability as a acid fermented bacteria in dadih. According to Nurmiati (2005), fermentation dadih can process because fermentative bacteria has naturally been transported in milk as its basic ingredients and in spontaneous fermentation of dadih involved lactic acid bacteria or some type of milk microbe in acidizing milk for dadih. The bacteria that form halo region on $\mathrm{GPA}-\mathrm{CaCO}_{3}$ medium are bacteria that can produce acids. Bacteria that grow by showing the halo area around the bacterial colony can be suspected as lactic acid bacteria because it can convert sugar into acid. Sugar utilized by bacteria will be simplified into organic acids that will hydrolyze $\mathrm{CaCO}_{3}$ in $\mathrm{GPA}-\mathrm{CaCO}_{3}$ medium. According to Hungate (1969) which states that the large halo area formed to be an indicator of the amount of acid production produced by bacteria.

Proteolytic bacteria are known to exist using SMA medium. Based on Table 1, the number of proteolytic bacteria in dadih Cubadak $98.10^{7} \mathrm{cfu} / \mathrm{g}$, followed by dadih from AiaAbu $16.10^{7} \mathrm{cfu} / \mathrm{g}$ and dadih from AiaSunsang $11.10^{7} \mathrm{cfu} / \mathrm{g}$. In dadihof Cubadak obtained the number of proteolytic bacteria is higher than other areas. The number of proteolytic bacteria in dadih product can be influenced by the $\mathrm{pH}$ value, the higher the $\mathrm{pH}$ value then the possibility of the greater the number of proteolytic bacteria. $\mathrm{pH}$ dadih of Cubadak region is 4.79, while $\mathrm{pH}$ dadih of AiaSunsang is 3,57 and $\mathrm{pH}$ dadih of AiaAbu is 3,82. Proteolytic bacteria that act as probiotic candidates can grow at acidic $\mathrm{pH}$, whereas proteolytic bacteria that tend to be bacterial decay can grow at neutral $\mathrm{pH}$ and alkaline $\mathrm{pH}$. This is supported by Nurmiati et al., (2007) who revealed that acid or low $\mathrm{pH}$ conditions resulted in the number of natural decaying bacteria in milk depressed growth, while the condition of neutral to alkaline $\mathrm{pH}$ resulted in bacterial decay tends to grow rapidly. Here is a picture of the existence of proteolytic natural bacteria in several dadih Lembah Gumanti in SMA medium.

Based on Figure 3 can be seen the existence of natural bacteria of proteolytic dadih in SMA medium. The use of SMA medium because SMA medium is a medium used to see proteolytic bacteria. Proteolytic bacteria can be seen from the formation of halo areas around bacterial colonies in medium SMA. According to Alexander (1971) halo region formed due to the protease that is able to lyse of protein in the medium. Bacteria can hydrolyze the casein in milk into peptides and simple amino acids.

Fresh milk is a perishable food (especially damaged) mainly due to the activity of bacterial decay in it. Milk rich in nutrients and lots of water are indeed a suitable medium for the growth and development of microorganisms. Generally in fresh milk there are hundreds of thousands to millions of bacterial cells of decay. The decaying bacteria in milk products can be found at neutral to alkaline $\mathrm{pH}$.

The acquisition of acid fermentative bacteria and proteolytic as well as the $\mathrm{pH}$ value of each dadih can affect the quality of dadih. Based on Table 1, it is known that the best dadih quality 
were dadih from AiaSunsang and AiaAbu regions. The quality of the dadih is determined by the physical qualities that include colour, aroma, taste, texture, viscosity and chemical quality determined by nutrition, acidity values (pH) and total bacterial. According to Henkenjohann and Muermann (1998) a good quality ofprobiotic products has to contain at least $10^{6}$ colony-forming units bacteria/gram.

\section{Isolates of potential natural bacteria in dadih}

For the selection of potential bacteria isolates in dadih was used $\mathrm{GPA}-\mathrm{CaCO} \mathrm{O}_{3}$ medium, because in this medium can be seen the existence of fermentative potential bacteria and bacteria that can be used as probiotic candidate (Fig. 4 and 5).

Colonies of bacteria that have large halo diameter and small diameter colonies are characteristic of acid fermentative potential bacteria, whereas bacterial colonies that have large halo diameter and large colony diameter are probiotic candidate bacteria characters. Two colonies of each region were selected according to this criteria, they were $\mathrm{DCU}_{1}$ and $\mathrm{DCU}_{2}$ from Cubadak, DAS 1 and $\mathrm{DAS}_{2}$ from AiaSunsang and $\mathrm{DAA}_{1}$ and $\mathrm{DAA}_{2}$ from ia Abu.

Isolates $\mathrm{DCU}_{1}, \mathrm{DAS}_{1}$ and $\mathrm{DAA}_{1}$ are potential bacteria as probiotic candidates, due to the large diameter of colonies formed with large halo areas. The magnitude of the diameter of the colony and the diameter of the halo region indicates the bacteria can grow rapidly in large numbers. According to Berrada et al., (1991) cit. Chou and Weimer, (1999) one of the conditions for probiotic microbes to survive in stomach acid conditions for 90 minutes. According to Salminen et al., (1998), probiotic microbes can be stable against low $\mathrm{pH}$ of stomach acid and bile salts. All three isolates showed that the colonies of these bacteria could grow and survive in acidic medium conditions. Evidenced by the occurrence of bacterial hydrolysis of the acid in the GPA medium $\mathrm{CaCO} 3$ added. According Tannock (1999), which states the number of bacterial cells that must be contained in the probiotic products and health benefits of $10^{6}$ $10^{8} \mathrm{cfu} / \mathrm{g}$. According to Charterist et al., (1998) the number of probiotic bacterial cells ranges from $10^{7}$ to $10^{8} \mathrm{cfu} / \mathrm{g}$. According to Bouhnik (1993) which states that the number of probiotic microbes after passing through the digestive tract $10^{6}-10^{7} \mathrm{cfu} / \mathrm{g}$.

Probiotics are known as good bacteria that can provide benefits to its host. Naidu and Clemens (2000) cit. Usmiati (2011) revealed that probiotic activity is divided into three aspects, namely nutrition, physiological and antimicrobial effects. The nutritional aspect may be the provision of enzymes (lactase) to help metabolize food components, synthesize some types of vitamins ( $\mathrm{K}$, folate, pyridoxine, pantothenic, biotin and riboflavin) and produce toxins from metabolites of food components in the gut.

Physiological aspects include the ability to maintain a balance of intestinal microflora composition and stimulate the intestinal immune system. Aspects of antimicrobial effects include the ability to increase against the negative effects of pathogenic microbes.

Isolates $\mathrm{DCU}_{2}, \quad \mathrm{DAS}_{2}$ and $\mathrm{DAA}_{2}$ are fermentative potential bacteria, this is because of the large diameter of the halo area formed by the small diameter of bacterial colonies. The large diameter of the halo area but has a small diameter of bacterial colonies indicates the bacteria has a high fermentation ability, the halo area formed is an acid produced by bacterial colonies. All three isolates can ferment glucose in $\mathrm{GPACaCO} \mathrm{C}_{3}$ medium to produce acid. 
Table.1 The presence of microflora in several dadih products in specific medium

\begin{tabular}{l} 
Microflora \\
\hline Total \\
\hline Acid-Fermentative $\left(\mathrm{GPA}+\mathrm{CaCO}_{3}\right)$ \\
\hline Proteolytic (SMA) \\
\hline pH
\end{tabular}

\begin{tabular}{|c|c|c|}
\hline \multicolumn{3}{|c|}{ Total of Microflora (... x 10 $\mathbf{~ c f u / g ) ~}$} \\
\hline Dadih Cubadak & Dadih AiaSunsang & Dadih Aia Abu \\
\hline 142 & 185 & 138 \\
\hline 14 & 70 & 60 \\
\hline 98 & 11 & 16 \\
\hline 4,79 & 3,57 & 3,82 \\
\hline
\end{tabular}

Table.2 Character of Potential-Isolate in Dadih Product of Lembah Gumanti

\begin{tabular}{|c|c|c|c|c|c|c|}
\hline \multirow[t]{2}{*}{ Character } & \multicolumn{6}{|c|}{ Isolate } \\
\hline & DCU1 & DCU2 & DAS1 & DAS2 & $\mathbf{D A A}_{1}$ & $\mathbf{D A A}_{2}$ \\
\hline $\begin{array}{l}\text { 1. } \text { Macroscopis } \\
\text { a. } \quad \text { Colony shape } \\
\text { b. } \quad \text { Colony edge } \\
\text { c. } \quad \text { Colony elevation } \\
\text { d. } \quad \text { Colony colors }\end{array}$ & $\begin{array}{l}\text { Circular } \\
\text { Undulate } \\
\text { Raised } \\
\text { White }\end{array}$ & $\begin{array}{l}\text { Circular } \\
\text { Entire } \\
\text { Raised } \\
\text { White }\end{array}$ & $\begin{array}{l}\text { Circular } \\
\text { Undulate } \\
\text { Raised } \\
\text { White }\end{array}$ & $\begin{array}{c}\text { Spindle } \\
\text { Entire } \\
\text { Raised } \\
\text { Yellowish white }\end{array}$ & $\begin{array}{l}\text { Circular } \\
\text { Entire } \\
\text { Raised } \\
\text { White }\end{array}$ & $\begin{array}{c}\text { Spindle } \\
\text { Entire } \\
\text { Flat } \\
\text { White }\end{array}$ \\
\hline $\begin{array}{l}\text { 2. } \\
\text { Microscopis } \\
\text { a. } \quad \text { Cell shape } \\
\text { b. } \quad \text { Gram } \\
\text { c. } \quad \text { Motility }\end{array}$ & $\begin{array}{c}\text { Coccus } \\
+ \\
\text { Non-motile }\end{array}$ & $\begin{array}{c}\text { Coccus } \\
+ \\
\text { Non-motile }\end{array}$ & $\begin{array}{c}\text { Bacilli } \\
+ \\
\text { Motile }\end{array}$ & $\begin{array}{c}\text { Bacilli } \\
+ \\
\text { Motile }\end{array}$ & $\begin{array}{c}\text { Bacilli } \\
+ \\
\text { Motile }\end{array}$ & $\begin{array}{l}\text { Bacilli } \\
+ \\
\text { Motile }\end{array}$ \\
\hline $\begin{array}{l}\text { 3. } \text { Biochemichal } \\
\text { a. } \quad \text { Catalase test } \\
\text { b. } \quad \text { KOH test } 3 \%\end{array}$ & $\begin{array}{l}- \\
-\end{array}$ & $\begin{array}{l}- \\
-\end{array}$ & $\begin{array}{l}- \\
-\end{array}$ & - & - & - \\
\hline Fermentative Index & 1,4 & 1,1 & 1,25 & 3 & 1,25 & 2 \\
\hline
\end{tabular}

Description: (+): positive and (-): negative

Fig.1 Bamboo Gombong (Gigantochloaverticillata) from A) Cubadak, B) AiaSunsang and C) AiaAbu

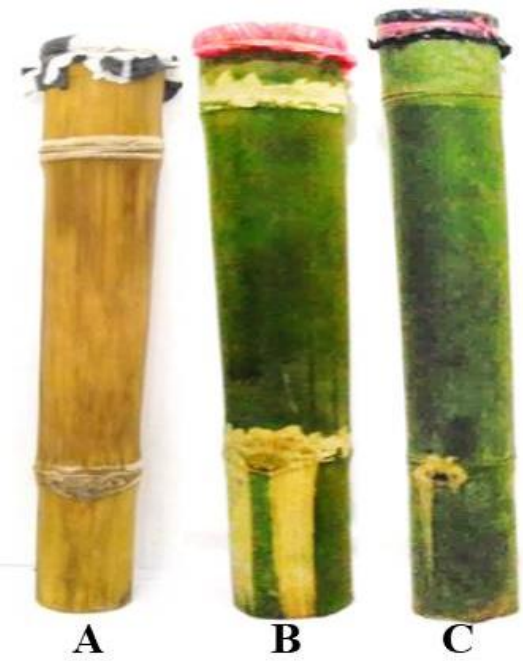


Fig.2 The presence of dadih natural microflora from several locations in LembahGumanti A) Cubadak, B) AiaSunsang, C) AiaAbu.
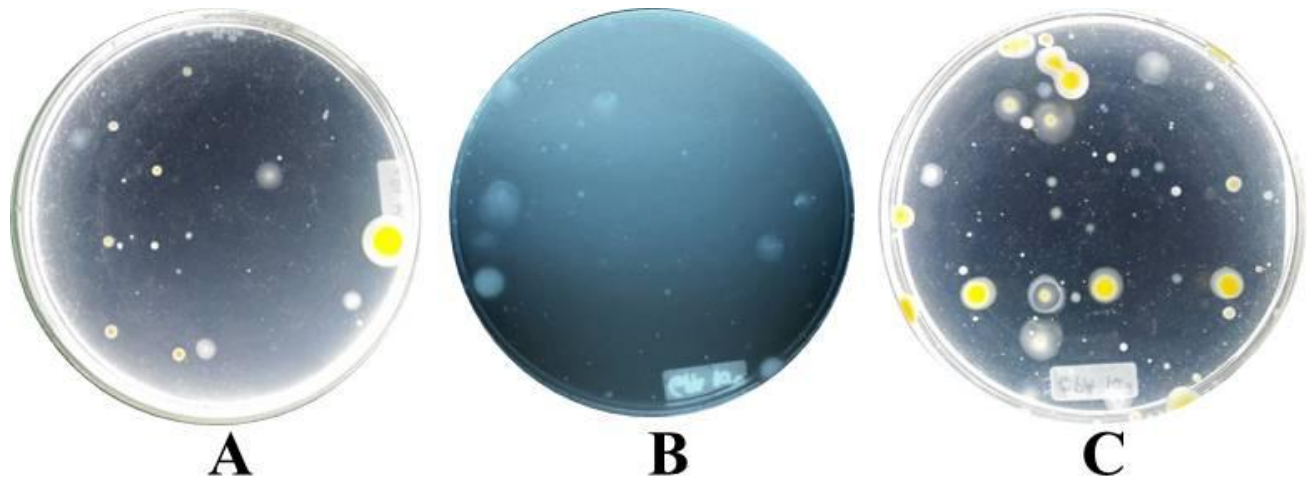

Fig.3 The presence of dadih natural fermentative bacteria from several locations at LembahGumanti in $\mathrm{GPA}+\mathrm{CaCO}_{3}$ medium, A) Cubadak, B) AiaSunsang, C) AiaAbu

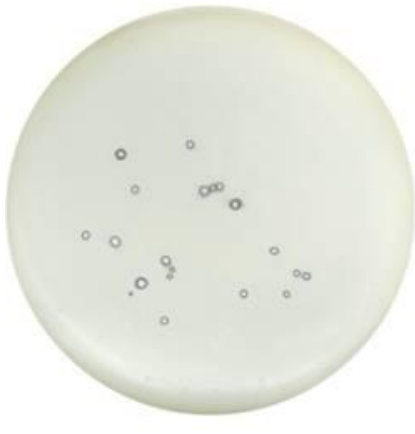

A

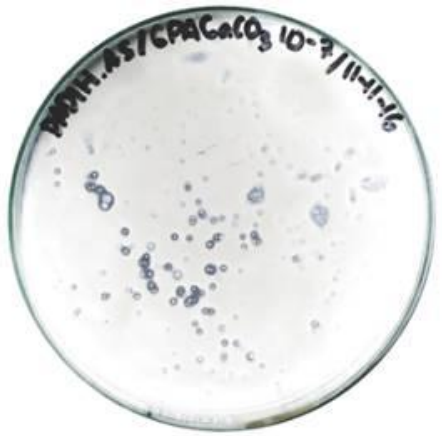

B

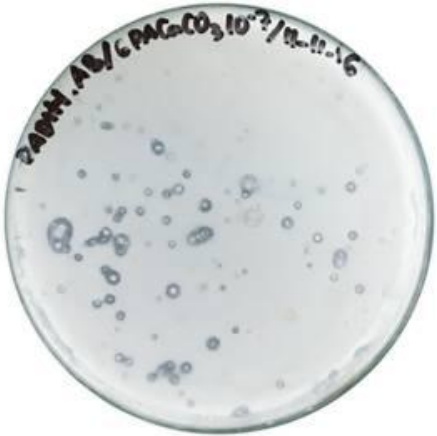

C

Fig.4 The presence of dadih proteolytic natural bacteria in SMA medium. A) Cubadak, B) AiaSunsang, C) AiaAbu

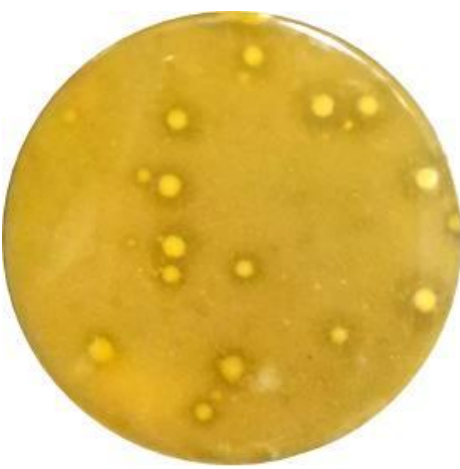

A

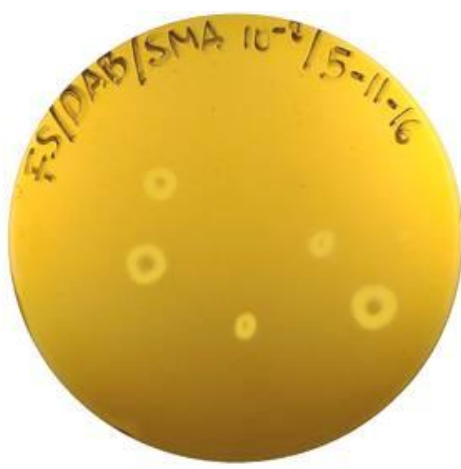

B

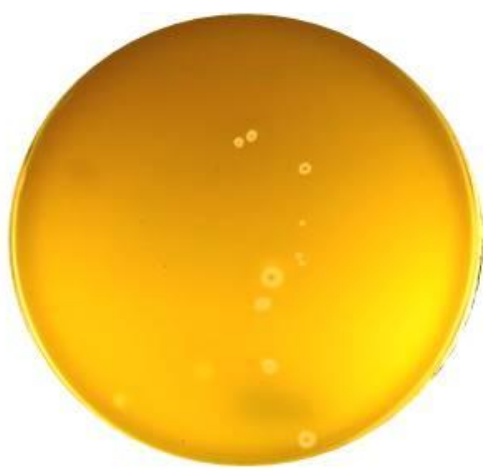

C 
Fig.5 Microscopic of all dadih isolates after Gram staining

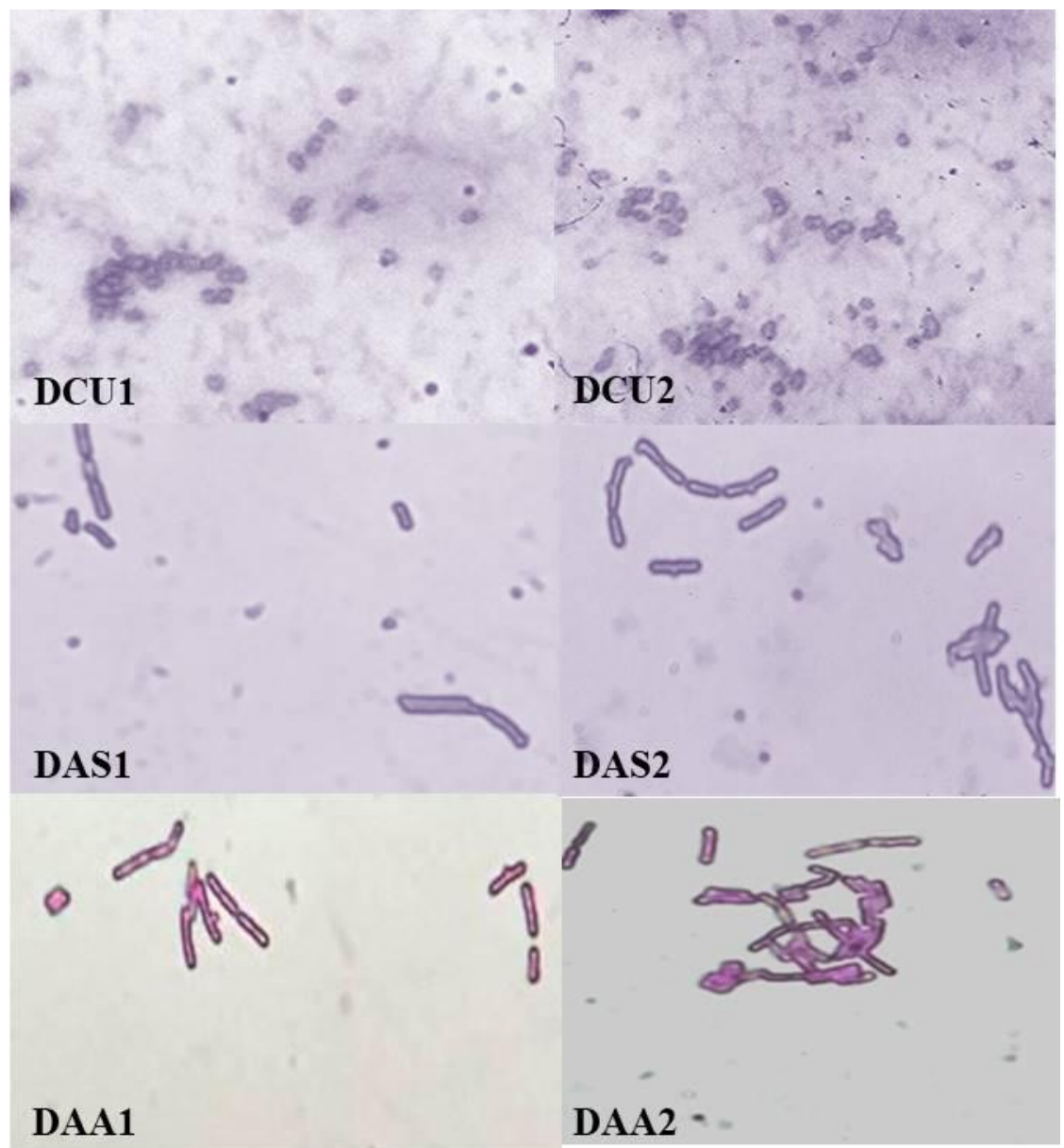

This is in accordance with Nurmiati (2007), which states that the ability of bacteria fermentation can be seen from the ability of bacteria in producing the acid depicted in the length of the halo area, the longer the halo area formed, the bacteria colony's ability to produce more and more acid.

\section{Isolates character of fermentative potential bacteria in Dadih}

Based on macroscopic and microscopic observation of colony-shape, -edge, elevation, -color, cell shape, Gram staining, motility and biochemical-test, which includes catalase-test and $\mathrm{KOH}$-test from both potential isolates in product from Cubadak, then the results obtained in Table 2.
Table 2 shows the macroscopic, microscopic and biochemical observations of bacterial isolates in dadih in all region Cubadak. All of the isolates have different macroscopic characters as well as some of the same characters. All isolates have a circular or spidle colonic shape with the edges of the undulateor entired colony. In microscopic characters, the $\mathrm{DCU}_{1}$ and $\mathrm{DCU}_{2}$ isolates have the same microscopic character, they are coccus, other isolates are bacilli, and they all are Gram positive, non-motile or motile cellsannegative catalase.

Visually visible characters are macroscopic characters of bacteria that are likely to be influenced by environmental factors that substrates used as medium and incubation 
temperatures. Observations of microscopic characters of each isolate include Gram staining, cell shape, motility and endospores. The following are observations of microscopic isolates of $\mathrm{DCU}_{1}, \mathrm{DCU}_{2}, \mathrm{DAS}_{1}$, $\mathrm{DAS}_{2}, \mathrm{DAA}_{1}$ and $\mathrm{DAA}_{2}$.

Based on microscopic observations of Gram staining all of the isolates are showed as Gram positive isolates that characterized by the presence of purple bacterial cells. The isolates DCU1 and DCU2 are coccus and the isolates DAS1, DAS2, DAA1 and DAA2 arebacilli. The results of this Gram staining is also confirmed by $\mathrm{KOH}$ test. Bacterial cells do not appear to form mucus in a $3 \% \mathrm{KOH}$ solution. The results have confirmed that all isolates are gram positive.

\section{Motility test of bacterial isolates}

Based on Motility test of bacterial isolates in dadih from Cubadak, Aia Sunsang and AiaAbu in NAsemisolid medium, can be seen that the isolates in dadih of Cubadak, AiaSunsang and Cubadak areas are motile and non-motile. Isolates $\mathrm{DCU}_{2}, \mathrm{DAS}_{2}, \mathrm{DAA} 1$ and $\mathrm{DAA}_{2}$ are motile, characterized by bacterial growth spreading in $N A$ semisolid medium. Isolates $\mathrm{DCU}_{1}$ and $\mathrm{DAS}_{1}$ are nonmotile, characterized by bacterial growth confined to the needle puncture area.

\section{Catalase test}

All of Dadih isolates produced no air bubbles in catalase test, this indicates that all of these bacterial isolates are negative catalases. The negative catalase is characterized by the absence of air bubbles when bacterial isolates are dropped with a $3 \% \mathrm{H}_{2} \mathrm{O}_{2}$ solution. The catalase is positive if air bubbles form when the bacterial isolate is dropped with a $3 \%$ $\mathrm{H}_{2} \mathrm{O}_{2}$-solution. The formation of air bubbles indicates that the isolates need oxygen in their growth. According to Cappuccino and
Sherman (2005) the presence of air bubbles in the catalase test with $3 \% \quad \mathrm{H}_{2} \mathrm{O}_{2}$ solution indicates a decomposition reaction of Hydrogen Peroxide by catalase enzyme produced by microorganisms. According to Locke et al., (2013) catalase is an enzyme that can catalyze the decomposition of Hydrogen Peroxide into water and oxygen. According to Lay (1994) Hydrogen Peroxide is formed in aerobic metabolism, so microorganisms that grow in the aerobic environment must decompose the toxic material.

Based on macroscopic characterization, microscopic and biochemical test, and identification based on Bergey's Manual of Determinative Bacteriology, it is assumed that from six isolates, two strains of bacteria are Streptococcus and Lactobacillus. Isolates $\mathrm{DCU}_{1}$ and $\mathrm{DCU}_{2}$ are Gram positive, coccus and catalase negative bacteria. The character indicates that both isolates are bacteria from Streptococcus genus so that two types of isolates are Streptococcus sp1. and Streptococcus sp2. This is in accordance with Bergey's Manual of Determinative Bacteriology that bacteria of the Streptococcus species are Gram positive, catalase negative and sometimes motile and can be found in milk and dairy products.

Isolates $\mathrm{DAS}_{1}, \mathrm{DAS}_{2}, \mathrm{DAA}_{1}$ and $\mathrm{DAA}_{2}$ are Gram positive, bacilli, non sporeforming and negative catalase. The character indicated that the four isolates were bacteria from Lactobacillus genus, so that four isolates were Lactobacillus sp1, Lactobacillus sp2, Lactobacillus sp3 and Lactobacillus sp4. This corresponds to Bergey's Manual of Determinative Bacteriology that Lactobacillus bacteria belong to Gram-positive, rod-shaped, unported, non-motile and negative catalase. Lactobacillus bacteria is usually not motile, but there may also be motile bacteria, a motile Lactobacillus type using flagellum of the peritrich flagellum type. Lactobacillus can be 
found in animal and vegetable products, in the digestive tract especially in the small intestine of various warm-blooded animals including humans.

\section{Pathogenicity test}

The pathogenic test of the dadih bacteria has been done through hemolysis tests on blood agar medium. The six bacteria (two isolates of each region) showed the negative test results which is indicated by the absence of halo zone or haemolysis zone around the bacterial colonies. The absence of the haemolytic zone indicates that the isolates were not able to lysis erythrocytes. This is in accordance with Mc. Kane and Kandel (1998) on solid media for blood, the bacterium that produces haemolysin will show the colour change in the bacterial growth zone. Bacteria that have the ability to damage erythrocytes show clear zones around colony growth in Blood Agar and grouped as $\beta$-haemolytic bacteria and when around colony growth exhibits unlogged zones are incorporated into groups of $\alpha$-haemolytic bacteria and bacteria, which lack the ability to destroy erythrocytes grouped into groups of non-haemolytic bacteria.

\section{Lactate- or acetic-acid bacteria group test}

Lactic acid or acetic acid group test using Ethanol Calcium Carbonate $\left(\mathrm{EtOH}+\mathrm{CaCO}_{3}\right)$ Medium was performed to determine the group of bacteria (lactic-or acetic acid bacteria) isolated from dadih. Six isolates scratched on $\mathrm{EtOH}+\mathrm{CaCO}_{3}$ medium did not form halo areas, indicating that the isolates were not classified as acetic acid bacteria, but were a class of lactic acid bacteria. Acetic acid bacteria will form the halo zones on $\mathrm{EtOH}+\mathrm{CaCO}_{3}$ medium, because only acetic acid bacteria can oxidize ethanol to acetic acid which then dissolves the calcium around the bacterial colony (Periadnadi and Nurmiati,
2010). In this research, we found LAB from the genus Streptococcus and Lactobacillus. According to Ray and Bhunia (2008) lactic acid bacteria is a group of bacteria capable of converting carbohydrates in the form of glucose into lactic acid. According to Axelsson (2004) lactic acid bacteria are associated with nutrient-rich habitats such as milk, meat, vegetables, but some are mouth, intestinal, and vaginal microflora of mammals.

Lactobacilli are widespread in nature and many species have found applications in the food industry. They are generally the most acid tolerant of the LAB and will, therefore terminate many spontaneous lactic fermentations such as silage and vegetable fermentations (Kashket, 1987; Daeschel, et al., 1987 in Salminen and Wright, 1993).

Dadih is a product of buffalo milk with process of making a spontaneous or natural fermentation process. This is supported by Holzapfel et al., (1995) that lactic acid bacteria are closely related to traditional food fermentation and include classes of microorganisms that are safe to add in food, due to their non-toxic and non-toxic properties often referred to as food grade microorganisms or so-called Generally Recognized as Safe (GRAS) microorganisms are microorganisms that are not at risk to health. According to Reid et al., (2003) lactic acid bacteria also includes probiotic bacteria, it is live microorganisms that when given in certain amounts provide benefits to its host such as prevent diarrhea to keep the balance of intestinal flora, prevent cancer and decrease cholesterol.

Based on the research that has been done then got the following conclusion. The composition of presence acid fermentative bacteria in dadih from AiaSunsang and AiaAbu higher than proteolytic bacteria, 
while dadih from Cubadak showed that proteolytic bacteria higher than acid fermentative bacteria.

Isolate $\mathrm{DCU}_{1}$ and $\mathrm{DCU}_{2}$ of dadih from Cubadak were Gram-positive bacteria and cocci, it included to Streptococcus bacteria. Isolate $\mathrm{DAS}_{1}, \mathrm{DAS}_{2}, \mathrm{DAA}_{1}$ and $\mathrm{DAA}_{2}$ of dadih from AiaSunsang and AiaAbu were Gram-positive bacteria and bacill, it included to Lactobacillus bacteria.

All of the 6 isolates are not pathogenic bacteria, can be grouped in to lactic acid bacteria and can be indicated as probiotic.

\section{Acknowledgement}

Pronounced thanks to the Dean of Faculty of Mathematics and Natuaral Sciences sfor funding this Research through the PSDM Research Grants of Andalas University ofthe year 2017.

\section{References}

Alexander, M. 1971. Microbial Ecology. John Wiley and Sons. New York.

Axelsson, L.T. 2004. Lactic Acid Bacteria: Clasification and Physiology. Di dalam: Lactic Acid Bacteria: Microbiological and Functional Aspect Third Edition. Salminen S, von Wright A dan Ouwehand A (Eds). Marcel Dekker Inc. New York.

Badan Pusat Statistik Kabupaten Solok. 2014. Kabupaten Solokdalam Angka. Katalog BPS: 1102001.1003.

Bergey's Manual of Determinative Bacteriology. 1957. 7th edn. Edited by R. S. Breed, E. G. D. Murray and N. R. Smith. Baltimore: The Williams and Wilkins Co.

Bouhnik, Y. 1993. Ingredient selection criteria for probiotic microorganism in functional dairy food. Int. J. Dairy Tech. 51: 123-135.

Brudnak, M.A. 2003. The Probiotic Solutions. Natures Best Kept Secret for Radiant Health Dragon Door Publications. Inc. United States.

Buckle, K.A., R.A. Edwards, G.H. Fleet dan M.C. Wootton. 1987. Ilmu Pangan. Penerjemah H. Purnomodan Adiono. UI Press. Jakarta.

Cappuccino, J.G dan N. Sherman. 2005. Microbiology a Laboratory Manual $7^{\text {th }}$ $E d$. Pearson Education, Inc. Publishing as Benjamin Cummings. San Francisco.

Charterist, W.P., P.M. Kelly, L. Morelli and J.K. Collins. 1998. Ingredient Selection Criteria for Probiotic Microorganism in Functional Dairy Food. Int. J. Dairy Technol. 51(4): 123-135.

Chou, L.Z and B. Weimer. 1999. Isolation and characterization of acid and biletolerant isolates from strains of Lactobacillus acidophillus. J. Dairy Sci, 80: 23-31.

Czermak, P. 1993. Lebensmittel technologie. CIT Verlag. Darmstadt. Germany.

Donhauser, R. M., 1997. Quark, Butter, Joghurt, Kaesehausgemacht. W. Ludwig Buchverlag Muenchen. ISBN 3-77873545-4.

Etienne A., A. Datry and N. Gaspar. 2008. Successful Treatment of Disseminated Geotrichumcapitatum Inf ection with a Combination of Caspofungin and Voriconazole in an Immunocompromised Patient. Mycoses. 51 (3):270-2. doi:10.1111/j.1439 0507. 2007. 01484. xPMID18399909.

Fueller, R. 1989.Probiotics in Man and Animals.J. Appl. Bacteriol. Vol 66. Hal 365-378.

Henkenjohann K. und B. Muermann, 1998. Milch und Milcherzeugnisse. AID Verlag. Wuerzburg. ISBN 3-89661230-1. 
Hungate, R.E. 1969. A roll tube for cultivation of strict anaerobes. In Methods in microbiology. Vol 3B. Norris, J. R. And Ribbo, D. W. (eds). Academic Press. London.

Marlida, Y., Harnentis, Nurmiati, 2016. Isolation and Screening of Lactic Acid Bacteria from Dadih for Glutamic Acid Production as Precursor of $\gamma$-Amino Butyric Acid (GABA) Induced Heat Stress in Broiler, International Journal of Chem Tech Research Vol.9, No.12, pp 534-540, 2016

Nurmiati, Periadnadidan D. Amelia. 2007. Keberadaanmikrobaalamidanpenambah anprobiotikpembentuk aroma dalamfermentasidadih. Unpublished.

Nurmiati. 2005. Dadih produkprobiotikhasil fermentasitradisionalsusukerbaudansus usapi. Regularly Scientific SeminarTPSDP Batch III 2005. Biologi. Universitas Andalas.

Nurmiati.2006. Perkembangan Populasi Mikroba Dadih selama Fermentasi Susu Kerbaumentahdanpasteurisasi.

Semirata BKSPTN Wilayah Barat Bidang MIPA XIX 9-11 Juli 2006.

Nurmiatidan Periadnadi. 2010. Kajianpotensidan Selektifitas Probiotik Alamidalam Upaya Perbaikan Mutu Makanan Fermentasi Tradisional Dadih. in: A. Djamaan. Mikroorganismedan Pemanfaatannyadalam Berbagai Bidang. Universitas Andalas Press. Padang.

Osek, J. 2004. Phenotypic and genotypic characterization of Escherichia coli O157 strains isolated from human, cattle, and pigs. Vet. Med-Czech. 9:317-326.

Oxoid. 1998. The Oxoid Manual. 8th ed. Complied by E.Y. Bridson (Former Technical Director of Oxoid).

Pelczar, C.J and E.C.s. Chan. 1988.Elements of Microbiology. (diterjemahkan Hadioetomo, R.S., T. Imas, S.S. Tjitrososmodan S.I. Angka). Edisi ke1.Indonesia University Press. Jakarta.

Pelczar, C.J dan R.D. Reid. 1958. Microbiology. McGraw-Hill Book Company Inc. New York. Toronto. London.

Periadnadidan Nurmiati. 2010. Keberadaandan Isolasi Mikroflora dalambuah Tropis. Universitas Andalas. Unpublished.

Poerwadarminta.1976. Kamus Umum Bahasa Indonesia. Balai Pustaka. Jakarta.

Ray, B and A. Bhunia. 2008. Fundamental Food Microbiology. 4 th ed. CRC Press. United State of America.

Reid, G., J. Jass, M.T. Sebulsky and J.K. Mc.Cormick. 2003. Potential Uses of Probiotics in Clinical Practice. Clinical Microbiology Review 16 (4): 658-672.

Salminen, S., A. Ouwehand, Y. Beno and Y.K. Lee. 1999. Probiotic: How should they be defined.Trends in Food Science and Technololy 10 (Isue 3): 107-110.

Tannock, G.W. 1999. Probiotic: A Critical Review. Horizon Scientific Press. England. Pp 39-72.

Tauefel, Ternes, Tunger und Zobel. 1993. Lebensmittel Lexikon. Behrs Verlag GmbH. Hamburg.

\section{How to cite this article:}

Nurmiati, N., P. Periadnadi, F. Alamsyah and Sapalina, F. 2018. Characterization and Potential of Acid Fermentative and Proteolytic Natural Microflora in Several Products of Traditional Dadih from Lembah Gumanti District West Sumatra, Indonesia. Int.J.Curr.Microbiol.App.Sci. 7(03): 3151-3163. doi: https://doi.org/10.20546/ijcmas.2018.703.364 